ヨウ素製剤は抗菌力が強力であるばかりでなく，選択 性がないので，真菌の発育阻止の目的には効果が期待で きる己思われる，しかしての薬物には抗生物質に対する 強い破壊作用があり，また持続性が少ないという欠点が あるので，実際の使用は制約を受けるであ万う。この点 抗生物質に対して余り破壊作用を有しないホルマリン製 剂の方が臨床的には好ましいと考えられる。

歯科用フェノールチモールやヨードカルボール, ハウ 氏の硝酸銀溶液もかなり強い発育阻止作用を示した。し たがってこれらも十分考慮に值する製剤といえよう。

な挍，抗生物質之抗力ビ作用を有する楽物之を配合し た製剤の研究を行なっているが，つぎの機会に報告させ て戴きたい. (抄録)

\section{（宿題報告 II）}

脳卒中と動脉硬化

\section{九州䨑科大学内科学教授 岡部信彦 一势 録 久一一}

（本誌 $\mathrm{p} 168$ に摘録を揭載してあるので参照されたい）

\section{一般 講 演 抄 録}

\section{1. 蛙舌乳頭の反射連動について}

(九场大·生理) ○中原 飭・廖 伯毅 大曲統司明・野代平治

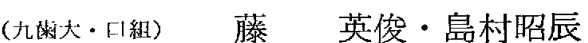

研究目的

蛙の舌を化学的に刺激するとき，舌下神経中に遠心性 インパルスの発生することについてはすでに発表した。 今回はこの舌下神経の遠心性インパルスによって舌によ゙ のような運動が起るがついて調べた。

\section{実験方法}

舌に Ringer's solution, $\mathrm{H}_{2} \mathrm{O}, 2.65 \%$ 以下の $\mathrm{NaCl}$, $3.65 \%$ 以上の $\mathrm{NaCl}, 10 \%$ Sucrose, Quinine, tartaric acidなどを注ぎ，実体顕微鏡下で舌及び舌乳頭の動きに ついて観察した。

舌の組織についてはへマトキシリン・エオジン染色に より舌乳頭の筋及び血管の観察を行なった。 また，乳頭 の感覚上皮の表面構造は走査型電子顕微鏡によって調べ た.

\section{実験成積}

組織学的に舌の乳頭を調べる己茸状乳頭, 糸状乳頭の いずれにあ数本の横紋筋線維が入っているのが認められ る. これらの筋線維は舌中の筋群から枝分れしたもので 乳頭の固有層を上行し，感覚上皮值下に終止しているも のである．な㧍，茸状乳頭中に環状に細血管あるいは毛
細血管が走っているのが認められる，電顕的には，感覚

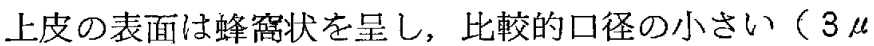
前後) Gastatory cell と大きい口径（6.2 10 $\mu$ 前後） の Supporting cell と思われるむのの配列からなってい る.Ciliary cell の存在ははっきりしなかった。

つぎに，実体顕微鏡で観察しながら舌上に Ringer’s solution, $2.65 \%$ 以下の $\mathrm{NaCl}, 10 \%$ Sucrose, $\mathrm{H}_{2} \mathrm{O}$ などを注いでも舌及び舌乳頭に運動は見られず，咠状乳 頭が長く突出しているのが観察された。

3.65\%以上の $\mathrm{NaCl}$, Tartaric acid, Quinine などを 注ぐとき舌乳頭に著明な運動が起るのが観察された。こ の運動は刺激局所に強く起とった。また，刺激を強める ときには，舌全体の運動となった。

結論

舌乳頭の運動は $\mathrm{H}_{2} \mathrm{O}, \mathrm{NaCl}$ の濃度 の低い場合及び 10\% Sucrose などの刺激では起らないこと, 強い刺激 によってのみ起るととから, このような強い刺激から逃 れるためのあのであるうと思われる。

\section{2. 左右側咬筋筋電図の比較について}

(九菌大·生理) $\bigcirc$ 大曲統司明 - 廖 伯毅 - 并上 功 中原 敏・野代平治

（九谈大・1 日外）池内孝彰・蒲池世史郎

研究目的

口腔領域に特別な疾患のない人について，左右の咬筋 及び側頭筋のEMGの大きさを比較検討した。

研究方法

特別に口腔内に疾患のないもの, 及び有林義歯を装着

していない18４6才の男女98名を対照とした．

記録には，脳波用の電極を用い単極誘導した，不関電 極は鼻根部に装置した。

記録部位は左右雨側の咬筋及び側頭筋の前部に扔いて 行なった。

被験者には，中心咬合を行なわせ記録されたEMGの 大きさを比較検討した。なお被験者の咀嚼習慣は，問診 や実際にピーナツを咀嚼させて判定した。

\section{実験成績}

同一被験者について，日を変えて 3 度の記録を行なっ たととろ，この3つの記録はすべて同じ傾向を示した。 特にこの記録のうち，1 年を経過したものも全く同じ大 きさの差異を示した。

つぎに，咬筋のEMGに差異を認めるあのと，認めら れないものの比率は次のようであった。すなわち，EM のに差異を認めたもの45\%，認めないすの46\%，判別の 